\title{
A Hierarchical Multiple Regression Approach on Determining the Effect of Psychological Capital on Entrepreneurial Intention amongst Prospective University Graduates in South Africa
}

\author{
Clifford Kendrick Hlatywayo, Chioneso Show Marange, Willie Tafadzwa Chinyamurindi \\ University of Fort Hare, South Africa \\ vakendie@gmail.com,marangecs@gmail.com,chinyaz@gmail.com
}

\begin{abstract}
The goal of the study is to identify the contribution of psychological capital in the prediction of entrepreneurial intention using the Theory of Planned Behaviour (TPB) as a theoretical lens. South Africa needs young entrepreneurs, not job seekers. However, in order to adapt, graduates must rely on psychological resources to succeed in their entrepreneurial ventures and pursuits. Using the TPB and Psychological capital (Psycap), the researchers explored the influence of planned behaviour and Pyscap on entrepreneurial intention of 270 final year students in the Management and Commerce faculty at a selected university in the Eastern Cape Province of South Africa. A structured questionnaire was used to collect data as the researchers opted for a survey design. Results of hierarchical multiple regression modelling showed that entrepreneurial intentions is positively influenced by perceived behavioural control $\left(\beta_{1}=0.367 ; p=<0.0001\right)$ attitudes towards becoming an entrepreneur $\left(\beta_{2}=0.316 ; p=<0.0001\right)$ and resilience $\left(\beta_{3}=0.130 ; p=0.009\right)$. The resultant model revealed that resilience $\left(\Delta \mathrm{R}^{2}=0.016 ; \mathrm{R}^{2}=0.392 ; \mathrm{df}=266 ; \mathrm{p}=0.009\right)$ was the only significant psychological capital construct that added unique variance in predicting entrepreneurial intention above and beyond, which is predicted by the theory of planned behavior variables among the prospective graduates. Findings of the study are helpful to policy makers as they try to optimise strategies for entrepreneurial success in the South African context and the developing world.
\end{abstract}

Keywords: Theory of planned behaviour, entrepreneurial intention, psychological capital, hope, resilience, optimism, self-efficacy, university students, prospective graduates, hierarchical regression

\section{Introduction}

The role of entrepreneurs in driving economic growth cannot be underwritten as global markets are characterised by increasing levels of unemployment. At the end of each academic calendar, universities produce thousands of young people for the world of work. In the South African context, entrepreneurship is becoming an area of high priority as the economy is weakening, thereby culminating to potential job losses. Consequently, most graduates are not absorbed due to a scarcity of jobs, among other factors. As such, it is advisable for graduates to become employers by adopting an entrepreneurial orientation. South Africa needs young entrepreneurs, not job seekers. The researchers propose that in order to adapt, prospective graduates must rely on psychological resources to succeed in their entrepreneurial ventures. Psychological capital has been identified by Luthans, Avey, Avolio, Norman and Combs (2006) as a predictor of performance and selffulfilment. Theoretically and empirically, psychological capital is positively related to higher performance and positive attitudes (Yousaf, Hizam-Hanafiah \& Usman, 2015). Although psychological capital is a new paradigm in the developed world, its benefits to entrepreneurship intention cannot be underwritten. However, it is recognised as a vital trait required by entrepreneurs to lead their businesses throughout their entrepreneurial practices (Yousaf et al., 2015). The researchers also assert that even though the benefits of positive psychology are known, there is little empirical literature on how psychological capital can be applied to entrepreneurs. In literature, entrepreneurship intention is identified as a key element in explaining entrepreneurial behaviour. It has also been established that there exists a link between entrepreneurial intention and the theoretical constructs of the theory of planned behaviour (Malebana \& Swanepoel, 2015; Kautonen et al., 2013; Herrington \& Kew, 2014; Kolvereid \& Isaksen, 2006; Zhang \& Yang, 2006; Delanoë, 2013). These theoretical constructs capture the three motivational factors which influence behaviour, namely: attitudes towards the behaviour, perceived social norms, and perceived behavioural control (Ajzen, 1991; Linan, 2004). The study is motivated by the recommendation for future studies by Malebana and Swanepoel (2015) who proposed that the link between entrepreneurial intention and behaviour would shed more light on the determinants of entrepreneurial behaviour in South Africa. The adoption of Psycap in the study is motivated as it is a breakaway from the traditional economic capital. As eluded by Luthans et al. (2006), the researchers are keen on exploring how positive psychology influences prospective graduates in the Management and Commerce Faculty at the selected university on entrepreneurial intention. The 
contributions of this study extend on the literature on Psycap and entrepreneurship intentions in the African context.

\section{Literature Review}

Entrepreneurship and planned behaviour: Benefits of entrepreneurship in any nation include job creation, innovation and economic growth (van Gelderen, Brand, van Praag, Bodewes, Poutsma \& van Gils, 2008). The relevance of entrepreneurship to economies in developing nations is viewed as a tangible way of lessening social employment pressures (Fenghua, Haibei \& Le, 2013). In the current environment, employment in organisations reduced due to the economic social and political changes (van Gelderen et al., 2008). There is no concise definition of the term entrepreneurship (Fenghua et al., 2013) as most in academia define it according to their objectives. The European Commission (2003) pronounces entrepreneurship with specific reference to the attitude reflected by a person's drive and aptitude to not only identify opportunities but pursue to produce economic benefits or new values. Entrepreneurship is an intentional activity (Henley, 2007) while its intention develops prior the creation of a new venture. Entrepreneurial intention presumably may predict entrepreneurial behaviour as it encompasses faith, attitude and intention (Fenghua et al., 2013). Needs, values, wants, habits and beliefs are factors identified, which influence intention preceding behaviour. Wong and Choo (2009) affirm intention as a critical predictor of entrepreneurial behaviour. The theory of planned behaviour, as interpreted in Linan (2004), constitutes the constructs that explain entrepreneurial intention. Fenghua et al. (2013) identify the consensus in the literature on how intention best predicts planned behaviour. Entrepreneurs, among other beneficiaries, are a source of innovation and new jobs creation (Yousaf et al., 2015).

In entrepreneurship theory, the theory of planned behaviour by Ajzen is the most celebrated theory (Küttim, Kallaste, Venesaar \& Kiis, 2014; Kautonen, Van Gelderen \& Tornikoski, 2013). The theory identifies intention as a determinant of behaviour (Ajzen, 2011). The theory has been validated and empirically tested by many scholars across the globe (Fenghua et al., 2013). Lortie and Castogiovanni (2015) affirm that the applicability of the theory stretches beyond the realm of entrepreneurship and extends to marketing, health sciences, psychology and tourism, to mention a few.In adopting the theory of planned behaviour, the researchers were attentive of critique on intention; intention does not always lead to the adoption of a behaviour (Conner \& Armitage, 1998; Hamid \& Isa, 2015). The theory of planned behaviour was adopted similar to (van Gelderen et al., 2008). It is identified as the most relevant in exploring subjective norms, perceived behaviour control and attitudes. The theory is applicable in any context which seeks to predict and study human behaviour (Küttim et al., 2014).

Psychological Capital: In defining psychological capital, the accepted criteria to operationalize the term includes: confidence/efficacy, optimism, hope, and resiliency (Luthans et al., 2006). Fenghua et al. (2013), in their definition of Psycap, simplified it to personality traits which affect individual productivity. Resilient people can turn pressure into motive rather than succumb to setbacks. They study new knowledge actively and creatively to improve their ability to recover (Keen, McCoy \& Powell, 2012). Regardless of risk and adversity, one who exudes resilience always seeks a positive outcome. Self-efficacy is identified by Bandura, self-belief in putting in place actions which meet the desired outcome. Hope dwells on the planning of a goaldirected energy to achieve a goal. Individuals with hope are resourceful and strong with creative ideas. When one is optimistic, they have positive expectations for the future regardless of circumstance. Optimistic individuals accept new ideas and have positive emotions (Luthans \& Youssef, 2004; Chen, Gully \& Eden, 2001; Masten \& Reed, 2002; Snyder, Irving \& Anderson, 1991; Oldham \& Hackman 1980; Mónico, Pais, dos Santos \& Santos, 2014; Luthans, Youssef \& Avolio, 2007; Gina \& Marthine, 2013). From the deconstructed psychological capital variables, an association can be inferred to entrepreneurial intention as theoretically and empirically psychological capital is positively related to performance (Yousaf et al., 2015). The study sought then to interrogate which attribute/s of psychological capital influence entrepreneurial intention in spite of people expressing themselves beyond a challenge.

Study objectives: The researchers sought to:

- identify the theoretical constructs of the theory of planned behavior and psychological capital which have a significant effect on entrepreneurial intention; and 
- Explore the extent to which psychological capital constructs add unique variance in predicting entrepreneurial intentions above and beyond as predicted by the theory of planned behaviour variables among prospective graduates.

Hypothesis: From the objectives stated above, we deconstructed the following hypotheses:

$\mathrm{H}_{1}$ Hope can affect prospective graduates' entrepreneurial intention.

$\mathrm{H}_{1 \mathrm{a}}$ Hope adds a unique variance in predicting entrepreneurial intention above and beyond as predicted by the theory of planned behavior variables among prospective graduates.

$\mathrm{H}_{2}$ Self-efficacy can affect prospective graduates' entrepreneurial intention.

$\mathrm{H}_{2 a}$ Self-efficacy adds a unique variance in predicting entrepreneurial intention above and beyond as predicted by the theory of planned behaviour variables among prospective graduates.

$\mathrm{H}_{3}$ Resilience can affect prospective graduates' entrepreneurial intention.

$\mathrm{H}_{3 \mathrm{a}}$ Resilience adds a unique variance in predicting entrepreneurial intention above and beyond as predicted by the theory of planned behaviour variables among prospective graduates.

$\mathrm{H}_{4}$ Optimism can affect prospective graduates' entrepreneurial intention.

$\mathrm{H}_{4 a}$ Optimism adds a unique variance in predicting entrepreneurial intention above and beyond as predicted by the theory of planned behaviour variables among prospective graduates.

$\mathrm{H}_{5}$ Attitudes towards becoming an entrepreneur can affect prospective graduates' entrepreneurial intention.

$\mathrm{H}_{6}$ Perceived behavioural control can affect prospective graduates' entrepreneurial intention.

$\mathrm{H}_{7}$ Close environment support (Subjective Norms) can affect prospective graduates' entrepreneurial intention.

\section{Methodology}

Participants: The respondents to the study were final year students in the Management and Commerce Faculty at the selected university in the Eastern Cape Province of South Africa. The researchers selected final year students in the Management and Commerce Faculty as they are essential clientele for entrepreneurship education in universities (van Gelderen et al., 2008). Convenience sampling was used to select the sample. The response rate of the survey was 0.84 as a total of 270 usable questionnaires were returned from the 320 distributed. Ethical clearance of the study was obtained from the ethics committee of the university. Each participant signed (prior participation) consent forms, and participation was voluntary. The researchers made sure to abide by the code of ethics, and anonymity of participants was observed to preserve respondent identity.

Measures: The researchers used the principle of one questionnaire per respondent. The research instrument comprised sections which measured psychological capital and its constructs, entrepreneurship intention, perceived behavioral control, subjective norms and attitudes towards becoming an entrepreneur. The variables were assessed with items rated on a 5 point Likert scale ranging from 1 (strongly disagree) to 5 (strongly agree). Dawkins, Martin and Scott (2013) identify the psychological capital questionnaire as the most frequently used instrument in the literature to measure psychological capital. To measure psychological capital and its four dimensions (hope resilience self-efficacy, and optimism), the PCQ 24 was opted, and it computed an alpha of 0.869. Questions on entrepreneurship intention, perceived behavioral control, subjective norms and attitudes towards becoming an entrepreneur were adopted from the Malebana and Swanepoel (2015) who designed their instrument from Linan and Chen (2009). The computed alpha values of these constructs ranged between 0.701 and 0.867 . These are high scores of reliability as the scores are above the prescribed 0.7; thus, research instruments are reliable.

Data Analysis: SPSS version 23 was used for analysis. All tests were carried out at a 5\% level of significance. Three research assistants independently entered all data with $100 \%$ verification, thus resolving any dataentry discrepancies. We used descriptive statistics to describe the sample's main demographic features (gender and age) and the T-Test to identify the mean gender differences that existed on psychological capital constructs among the prospective graduates. Pearson product-moment correlation coefficients ( $\mathrm{r}$ ) were used to identify correlates of entrepreneurial intention. A stepwise multiple linear regression model using the forward selection approach was used to determine the variables that have a significant effect on entrepreneurial intentions. The model included the theory of planned behaviour variables selected $a$ priori as 
predictors: perceived behavioral control, subjective norms and attitudes towards becoming an entrepreneur, and psychological capital constructs. In order to establish the amount of variation that each psychological capital construct adds in predicting entrepreneurial intention above and beyond, which is predicted by the theory of planned behaviour variables among prospective graduates, a hierarchical multiple regression model was used. Tests for normality were done using the normal plots of the standardized residuals. In accessing these plots, we found out that the points of the expected (against the observed) cumulative probabilities were lying on the line, thus the normality assumption for linear regression modeling was satisfied.

\section{Results}

Demographic profile of the respondents: Table 1 below shows the demographic results of the respondents. From the study sample $(n=270)$, the majority of the respondents $(55.9 \%, n=151)$ are male students, while female students comprised $44.1 \%$ of the respondents $(n=119)$. In terms of age, the majority of the respondents $(49.6 \%, n=134)$ are in the age group of $22-25$ years, while $23.7 \%(n=64)$ are below 21 years of age. A total of fifty-six respondents (20.7\%) fall in the age category 26-29 whilst only sixteen respondents $(5.90 \%)$ fall in the age category of 30 years and above.

Table 1: Descriptive Statistics for Demographic Variables

\begin{tabular}{lllll}
\hline Variable & Levels & df & f & \% \\
\hline Gender & Male & 1 & 151 & 55.9 \\
& Female & & 119 & 44.1 \\
Age & Below 21 yrs & 3 & 64 & 23.7 \\
& 22- 25 yrs & & 134 & 49.6 \\
& $26-29$ yrs & & 56 & 20.7 \\
& 30 yrs and above & 16 & 5.90 \\
\hline
\end{tabular}

$\mathrm{N}=270$, No missing data

Table 2: T-Tests for Mean Gender Differences on Study Variables

\begin{tabular}{|c|c|c|c|c|c|c|c|c|c|c|}
\hline \multirow{2}{*}{$\begin{array}{c}\text { Study } \\
\text { Variable }\end{array}$} & \multirow[t]{2}{*}{ Gender } & \multirow[t]{2}{*}{ Mean } & \multirow[t]{2}{*}{ SD } & \multicolumn{2}{|c|}{$\begin{array}{l}\text { Levene's Test } \\
\text { for Equality of } \\
\text { Variances }\end{array}$} & \multicolumn{5}{|c|}{ t-test for Equality of Means } \\
\hline & & & & $\mathbf{F}$ & Sig. & $\mathbf{t}$ & df & $\begin{array}{l}\text { Sig. (2- } \\
\text { tailed) }\end{array}$ & $\begin{array}{c}\text { Mean } \\
\text { Difference }\end{array}$ & $\begin{array}{l}\text { Std. Error } \\
\text { Difference }\end{array}$ \\
\hline \multirow[t]{2}{*}{ Self-Efficacy } & Male & 3.8223 & 0.71639 & 0.080 & 0.777 & -1.059 & 268 & 0.290 & -0.09367 & 0.08843 \\
\hline & Female & 3.9160 & 0.72774 & & & & & & & \\
\hline \multirow[t]{2}{*}{ Optimism } & Male & 3.8874 & 0.58644 & 0.038 & 0.845 & 0.148 & 268 & 0.882 & 0.01067 & 0.07193 \\
\hline & Female & 3.8768 & 0.58724 & & & & & & & \\
\hline \multirow[t]{2}{*}{ Hope } & Male & 3.7141 & 0.57329 & 0.103 & 0.749 & -1.753 & 268 & 0.081 & -0.12341 & 0.07039 \\
\hline & Female & 3.8375 & 0.57550 & & & & & & & \\
\hline \multirow[t]{2}{*}{ Resilience } & Male & 3.6308 & 0.66416 & 2.053 & 0.153 & -2.072 & 268 & $0.039 * *$ & -0.15597 & 0.07527 \\
\hline & Female & 3.7868 & 0.54373 & & & & & & & \\
\hline
\end{tabular}

$\mathrm{N}=270$, No missing data, Total number of Males $=151$ and of females $=119$ for all comparisons.

**Significant differences with equal variances assumed

*Significant differences with equal variances not assumed

Table 2 above depicts an independent-samples test which compared the means between male and female students' levels on the psychological capital constructs. Levene's test for homogeneity of variance (homoscedasticity) was used. This test verified that the assumption of equal variances holds in all samples. Significant differences in means between males and females were only noticed on resilience. Females (mean $=3.7868 ; \mathrm{SD}=0.54673)$ showed a significantly higher mean level of resilience than their male (mean $=3.6308 ; \mathrm{SD}=0.66416)$ counterparts $(\mathrm{t}=-2.072 ; \operatorname{Pr}>|\mathrm{t}|=0.039)$. This shows that female students had higher mean levels of resilience than male students. Pearson correlation analysis gave preparatory decomposition into the study variables. Table 3 illustrates the variables presented in the study. All the variables were significantly correlated to entrepreneurial intention. However, 'hope' had a somewhat statistically significant relationship with entrepreneurial intention $(r=0.118 ; p=0.054)$. Entrepreneurial 
intention was significantly positively correlated to self-efficacy $(r=0.158 ; \mathrm{p}=0.009)$, optimism $(\mathrm{r}=0.177 ; \mathrm{p}=$ $0.004)$, resiliency $(r=0.255 ; p=<0.0001)$, attitudes towards becoming an entrepreneur $(r=0.514 ; p=$ $<0.0001)$, perceived behavioral control $(\mathrm{r}=0.534 ; \mathrm{p}=<0.0001)$, and close environment support ( $\mathrm{r}=0.233 ; \mathrm{p}$ $=<0.0001$ ).

Table 3: Pearson product-moment correlations (r) and significance probabilities (p) for relations of entrepreneurial intentions to theoretical constructs

\begin{tabular}{|c|c|c|c|}
\hline & Theoretical Constructs & $\mathbf{r}$ & $\mathbf{p}$ \\
\hline \multicolumn{4}{|c|}{ Theory of planned behavior } \\
\hline 1 & Attitudes Towards Becoming an Entrepreneur & 0.514 & $<0.0001^{* *}$ \\
\hline 2 & Perceived Behavioral Control & 0.534 & $<0.0001^{* *}$ \\
\hline 3 & Close Environment Support & 0.233 & $<0.0001^{* *}$ \\
\hline \multicolumn{4}{|c|}{ Psychological Capital } \\
\hline 1 & Self-Efficacy & 0.158 & $0.009 * *$ \\
\hline 2 & Optimism & 0.177 & $0.004^{* *}$ \\
\hline 3 & Hope & 0.118 & 0.054 \\
\hline & Resilience & 0.255 & $<0.0001^{* *}$ \\
\hline
\end{tabular}

** Correlation is remarkable when the significant level is 0.01 (Two-tailed test).

* Correlation is remarkable when the significant level is 0.05(Two-tailed test).

Regression of psychological capital and theory of planned behaviour on entrepreneurial intentions: The stepwise procedure yielded a total of three significant models. Table 4 below shows that the first significant model was the one with perceived behavioural control as a predictor variable on entrepreneurial intentions $(\mathrm{F}=107.130 ; \mathrm{df}=1 ; \mathrm{p}=<0.0001)$. The standardized $\beta$ coefficients in Table 4 show that perceived behavioural control has a significant positive effect on entrepreneurial intentions $\left(\beta_{1}=0.534 ; t=10.350 ; p=\right.$ $<0.0001$ ). Multi-collinearity is non-existent in this linear regression model as tolerance was $>0.1$ (and VIF < 10) for the significant variable (perceived behavioural control). The resulting model yields:

(1) Entrepreneurial Intentions $=3.490+0.534^{*}$ Perceived Behavioral Control + residual $(\varepsilon)$

The second significant variable that was added to the model was 'attitudes towards becoming an entrepreneur' which yielded a significant model ( $F=80.466 ; \mathrm{df}=2 ; \mathrm{p}=<0.0001)$. The collinearity diagnostics in Table 4 shows that multi-collinearity does not exist in this $2^{\text {nd }}$ regression model (Tol $>0.1$ (or VIF $<10$ for all variables). Parameter estimates show that both perceived behavioural control and attitudes towards becoming an entrepreneur have a significantly positive effect on entrepreneurial intentions and the standardized regression coefficients are $\beta_{1}=0.377(p=<0.0001)$ and $\beta_{2}=0.339(p=<0.0001)$, respectively. Thus, the standardised regression equation of entrepreneurial intentions is:

(2) Entrepreneurial Intentions $=3.490+0.377^{*}$ Perceived Behavioral Control $+0.33{ }^{*}$ Attitudes towards Becoming an Entrepreneur + residual $(\varepsilon)$

Resilience was the last significant variable to be added to the regression model. This yielded a significant linear regression model $(\mathrm{F}=57.173 ; \mathrm{p}=<0.0001)$. Durbin-Watson test for auto-correlation $(\mathrm{d}=2.012)$ is between the two critical values of $1.5<\mathrm{d}<2.5$; therefore, we can assume that there is no first order linear auto-correlation in our multiple linear regression data. In table 4, the variance inflation factor (VIF) of each independent variable is between 1.052 and 1.304. According to the standard of statistical tests, a variance inflation factor (VIF) less than 10 and Tolerance greater than 0.1 indicated that a collinearity problem does not exist among variables. Thus, in the regression model, a collinearity problem does not exist among variables. The parameter estimates in Table 4 show that all the predictor variables, perceived behavioural control $\left(\beta_{1}=0.367 ; t=6.786 ; p=<0.0001\right)$, attitudes towards becoming an entrepreneur $\left(\beta_{2}=0.317 ; t=\right.$ 5.086; $\mathrm{p}=<0.0001)$ and resilience $\left(\beta_{3}=0.130 ; \mathrm{t}=2.642 ; \mathrm{p}=0.009\right)$ have a positively significant effect on entrepreneurial intentions. The resulting final model yields:

(3) Entrepreneurial Intentions $=3.490+0.367^{*}$ Perceived Behavioral Control $+0.317^{*}$ Attitudes Towards Becoming an Entrepreneur $+0.130^{*}$ Resilience + residual $(\varepsilon)$

Table 4: Parameter Estimates 


\begin{tabular}{|c|c|c|c|c|c|c|c|c|}
\hline & \multirow{3}{*}{ Model/Parameter } & \multicolumn{3}{|c|}{ Unstandardized Standardized } & \multirow{3}{*}{$\mathrm{T}$} & \multirow{3}{*}{ Sig. } & \multirow{2}{*}{\multicolumn{2}{|c|}{$\begin{array}{l}\text { Collinearity } \\
\text { Statistics }\end{array}$}} \\
\hline & & Coe & fficients & Coefficients & & & & \\
\hline & & B & Std. Error & Beta & & & Tol & VIF \\
\hline \multirow[t]{2}{*}{1} & (Constant) & 3.490 & 0.043 & & 80.587 & $.000^{*}$ & & \\
\hline & red Behavioral Control & 0.449 & 3 & 0.534 & 10.350 & $.000 *$ & 1.000 & 1.000 \\
\hline \multirow[t]{3}{*}{2} & (Constant) & 3.490 & 0.041 & & 86.072 & $.000^{*}$ & & \\
\hline & Perceived Behavic & 0.317 & 0.046 & 0.377 & 6.920 & $.000^{*}$ & 0.786 & 1.272 \\
\hline & $\begin{array}{l}\text { Attitudes Towards Becoming } \\
\text { Entrepreneur }\end{array}$ & an 0.285 & 0.046 & 0.339 & 6.223 & $.000^{*}$ & 0.786 & 1.272 \\
\hline \multirow[t]{4}{*}{3} & (Constant) & 3.490 & 0.040 & & 87.031 & $.000 *$ & & \\
\hline & Perceived Behavioral Control & 0.308 & 0.045 & 0.367 & 6.786 & $.000 *$ & 0.782 & 1.279 \\
\hline & $\begin{array}{l}\text { Attitudes Towards Becoming } \\
\text { Entrepreneur }\end{array}$ & an 0.266 & 0.046 & 7 & 5.806 & $.000^{*}$ & 0.767 & 1.304 \\
\hline & Resilience & 0.109 & 0.041 & 0.130 & 2.642 & $.009^{*}$ & 0.951 & 1.052 \\
\hline
\end{tabular}

Note; Dependent Variable: Entrepreneurial Intentions, *Significant effect.

Self-efficacy, optimism, hope and close environmental support were all non-significant and were excluded from the model (see Table 5 below).

Table 5: Excluded Variables

\begin{tabular}{|c|c|c|c|c|c|c|c|c|}
\hline \multirow{2}{*}{\multicolumn{2}{|c|}{ Model }} & \multirow[b]{2}{*}{ Beta In } & \multirow[b]{2}{*}{$\mathbf{T}$} & \multirow[b]{2}{*}{ Sig. } & \multirow{2}{*}{$\begin{array}{c}\text { Partial } \\
\text { Correlation }\end{array}$} & \multicolumn{3}{|c|}{ Collinearity Statistics } \\
\hline & & & & & & & & Minimum \\
\hline \multirow[t]{4}{*}{3} & Self-Efficacy & -0.019 & -0.357 & 0.722 & -0.022 & 0.821 & 1.219 & 0.749 \\
\hline & Optimism & -0.094 & -1.713 & 0.088 & -0 . & 0.749 & 1.336 & 0.727 \\
\hline & Hope & -0.043 & -0.761 & 0.447 & -0.047 & 0.730 & 1.370 & 0.716 \\
\hline & Close Environment Support & -0.005 & -0.103 & 0.918 & -0.006 & 0.845 & 1.183 & 0.710 \\
\hline
\end{tabular}

Note; Dependent Variable: Entrepreneurial Intentions

Predictors in the Model: (Constant), Perceived Behavioral Control, Attitudes Towards Becoming an Entrepreneur, Resilience

Below is the summary of the findings on the effects of the major study variables on entrepreneurial Intentions among the university's prospective graduates.

Figure 1: Summary of the conceptual model and hypothesis of psychological capital and theory of planned behaviour effect on prospective graduates' entrepreneurial intention. Note - Dependent Variable: Entrepreneurial Intentions; *Significant effect.

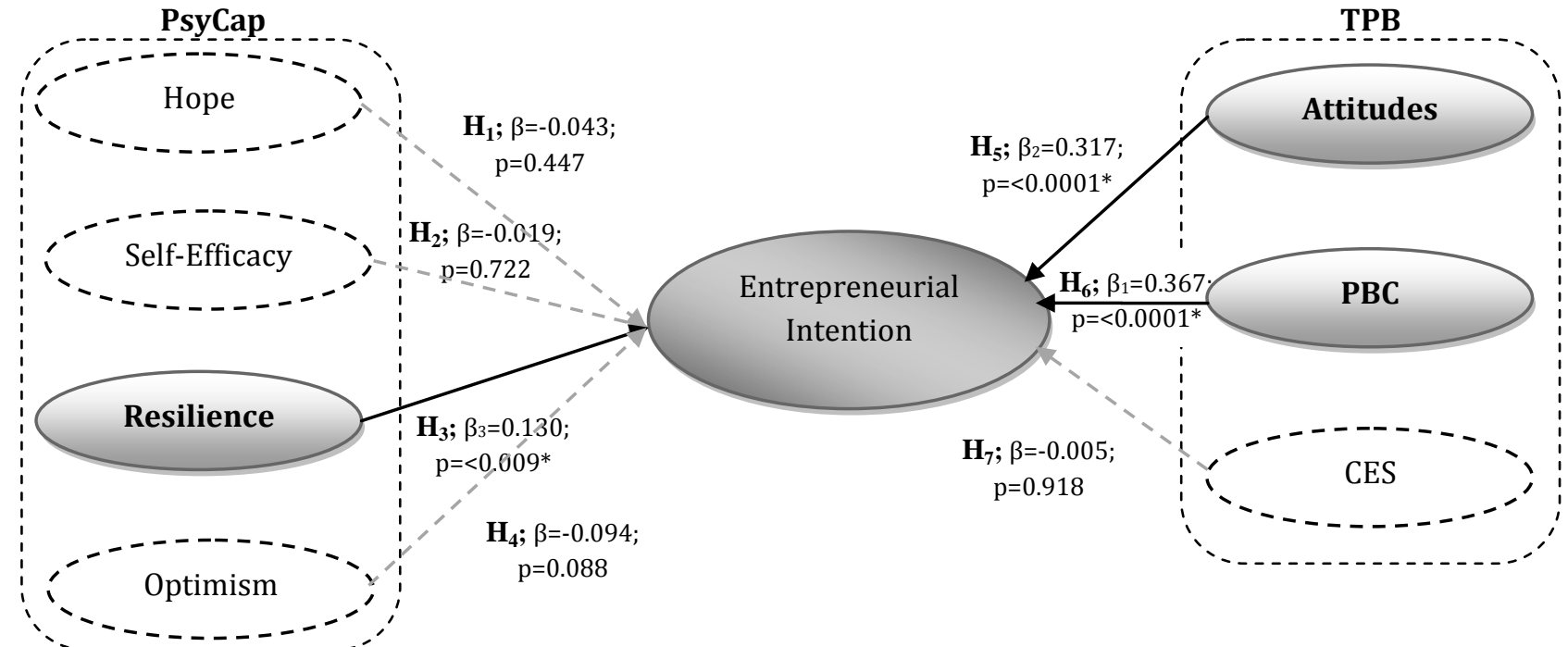

**kèy; PBC; percéived béhavioral control, CES; Closed environment support, TPB; theory of planned behavior. Hypothesis Hope $\left(\mathbf{H}_{\mathbf{1}} \mathbf{)}\right.$ : Hope can affect prospective graduates' entrepreneurial intention. 
Figure 1 above shows that hope does not significantly affect prospective graduates' entrepreneurial intention $(\beta=-0.043 ; p=0.447)$.

Hypothesis Self-Efficacy $\left(\mathbf{H}_{2}\right)$ : Self-Efficacy can affect prospective graduates' entrepreneurial intention.

Self-efficacy does not significantly affect prospective graduates' entrepreneurial intention $(\beta=-0.019 ; \mathrm{p}=$ 0.722 ).

Hypothesis Resilience $\left(\mathbf{H}_{3}\right)$ : Resilience can affect prospective graduates' entrepreneurial intention.

Resilience significantly affects prospective graduates' entrepreneurial intention $(\beta=0.130 ; p=0.009)$.

Hypothesis Optimism $\left(\mathbf{H}_{\mathbf{4}}\right)$ : Optimism can affect prospective graduates' entrepreneurial intention.

Optimism does not significantly affect prospective graduates' entrepreneurial intention $(\beta=-0.094 ; \mathrm{p}=$ 0.088 ).

Hypothesis Attitudes towards becoming an entrepreneur $\left(\mathbf{H}_{5}\right)$ : Attitudes towards Becoming an Entrepreneur can affect prospective graduates' entrepreneurial intention.

Attitudes towards becoming an entrepreneur significantly affect prospective graduates' entrepreneurial intention $(\beta=0.317 ; p=<0.0001)$.

Hypothesis Perceived behavioural control $\left(\mathbf{H}_{6}\right)$ : Perceived Behavioural Control can affect prospective graduates' entrepreneurial intention.

Perceived behavioural control significantly affects prospective graduates' entrepreneurial intention $(\beta=$ $0.367 ; \mathrm{p}=<0.0001$ ).

Hypothesis Close environment support (Subjective Norms) $\left(\mathbf{H}_{7}\right)$ : Close Environment Support (Subjective Norms) can affect prospective graduates' entrepreneurial intention.

Close environment support (Subjective Norms) does not significantly affect prospective graduates' entrepreneurial intention $(\beta=-0.005 ; p=0.918)$.

Hierarchical multiple regression analyses: To examine if the individual psychological capital constructs add unique variance in predicting entrepreneurial intentions above and beyond that which is predicted by the three theories of planned behaviour constructs hierarchical multiple regression models, were used. The predicting variables, perceived behavioural control, attitudes towards becoming an entrepreneur, close environmental support and the individual psychological capital constructs were added to the model in their respective order. At each stage, an additional explanatory variable was added to the model, and the change in $\mathrm{R}^{2}$ was noted. A hypothesis test using the $\mathrm{F}$-test was done to test whether the change in $\mathrm{R}^{2}$ is significant after addition of each of the psychological capital constructs to the theory of planned behaviour variables.

Table 6: A summary of hierarchical multiple regression analyses testing psychological capital and theory of planned behaviour constructs in the prediction of entrepreneurial intentions

\begin{tabular}{lllllll}
\hline \multicolumn{1}{c}{ Variable } & \multicolumn{5}{c}{ Entrepreneurial Intentions } \\
& $\boldsymbol{F}$ & $\boldsymbol{F} \boldsymbol{\Delta}$ & $\boldsymbol{R}^{\mathbf{2}}$ & $\boldsymbol{R}^{\mathbf{A}}$ & $\boldsymbol{d} \boldsymbol{f} \mathbf{2}$ & \multicolumn{1}{l}{ Sig. $\boldsymbol{F} \boldsymbol{\Delta}$} \\
\hline Perceived Behavioural Control & $107.130^{*}$ & & $0.286^{*}$ & $0.286^{*}$ & 268 & $<0.0001^{*}$ \\
Close Environmental Support & & 2.935 & 0.293 & 0.008 & 267 & 0.088 \\
Attitudes Towards Becoming an E. & & 35.271 & 0.376 & 0.083 & 266 & $<0.0001^{*}$ \\
aHope & & 0.413 & 0.377 & 0.001 & 265 & 0.521 \\
bSelf-Efficacy & 0.377 & 0.377 & 0.001 & 265 & 0.540 \\
cResilience & 6.961 & 0.392 & 0.016 & 265 & $0.009^{*}$ \\
dOptimism & & 0.334 & 0.377 & 0.001 & 265 & 0.564 \\
\hline
\end{tabular}

*Significant change in the amount of variation of dependent variable being explained by the predictors.

a. Predictors: (Constant), Theory of Planned Behaviour, Hope;

b. Predictors: (Constant), Theory of Planned Behaviour, Self -Efficacy

c. Predictors: (Constant), Theory of Planned Behaviour, Resilience;

d. Predictors: (Constant), Theory of Planned Behaviour, Optimism

Dependent Variable: Entrepreneurial Intentions

Table 6 above shows that perceived behavioural control explains $28.6 \%$ of the variation in the dependent variables $(\mathrm{R}$-Square $=0.286)$. Combined with attitudes towards becoming an entrepreneur, the resultant model accounted for a total of $37.6 \%$ of the variation in entrepreneurial intentions. Thus, this model adds significant variation to the first model. This means adding attitudes towards becoming an entrepreneur to 
perceived behavioural control as independent variables on entrepreneurial intentions results in a significant increase in the amount of variation explained by the model $\left(\Delta \mathrm{R}^{2}=0.83 ; \Delta \mathrm{F}=35.271\right.$; $\left.\operatorname{Sig} \Delta \mathrm{F}=<0.0001\right)$. For the psychological capital constructs, only resilience added a significant unique variance in predicting entrepreneurial intention above and beyond, which is predicted by the theory of planned behaviour variables among university students. Thus, a total of $39.2 \%$ of the variation in entrepreneurial intentions is explained by the final model. Thus, adding resilience to perceived behavioural control, attitudes towards becoming an entrepreneur and close environmental support,as independent variables on entrepreneurial intentions, results in a significant increase in the amount of variation explained by the model $\left(\Delta \mathrm{R}^{2}=0.016 ; \Delta \mathrm{F}=6.961\right.$; $\operatorname{Sig} \Delta \mathrm{F}=0.009$ ). The findings of the hierarchical multiple regression analyses are presented in Figure 2 below.

Fig 2: Summary of the hierarchical multiple regression conceptual model and the hypothesis of psychological capital constructs in adding unique variance in predicting entrepreneurial intention above and beyond, which is predicted by the theory of planned behaviour variables among prospective graduates. Note - Dependent Variable: Entrepreneurial Intentions; *Significant effect.

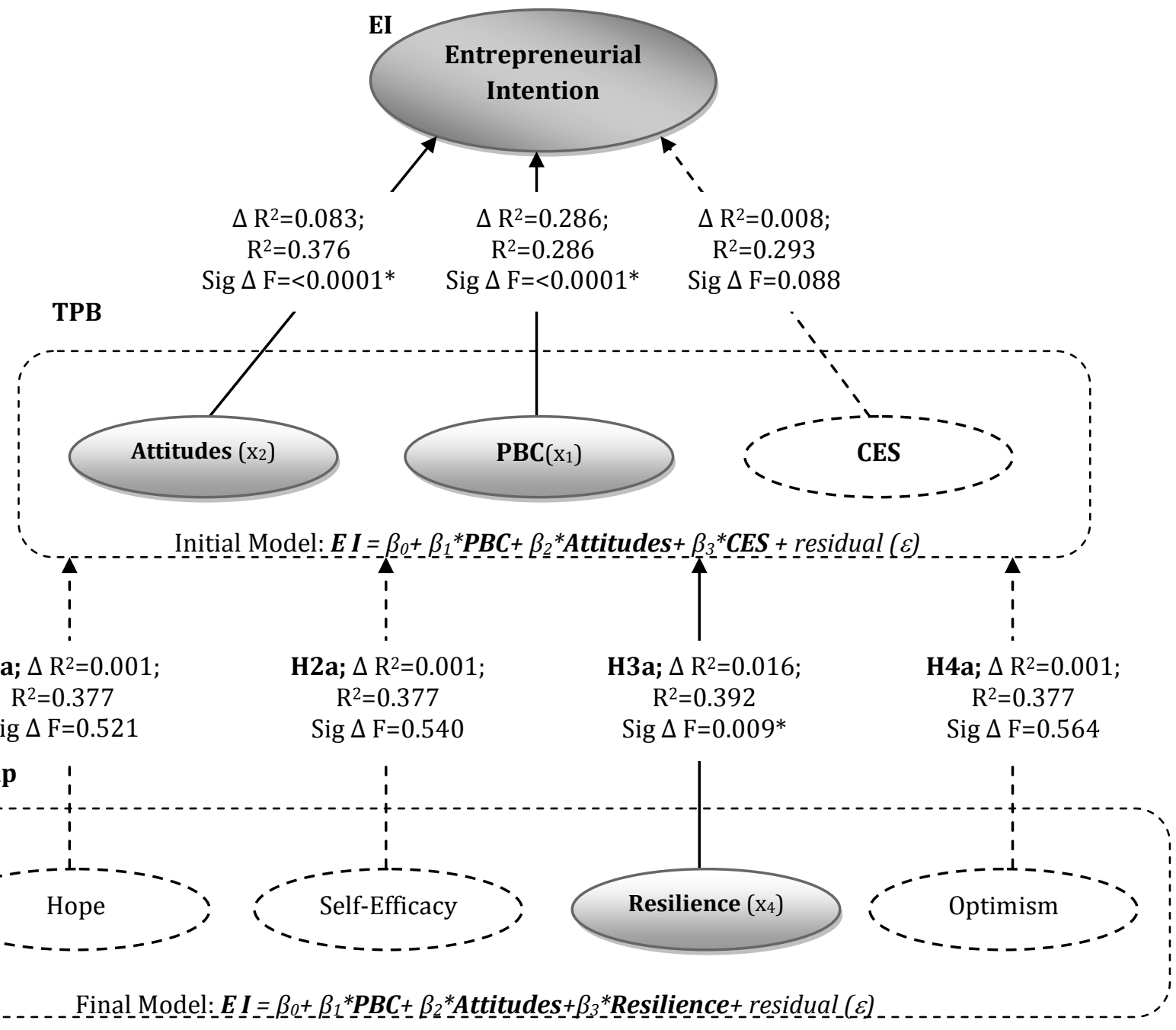

**key; PBC; perceived behavioral control, CES; Closed environment support, TPB; theory of planned behaviour

Hypothesis Hope $\left(\mathbf{H}_{1 \mathbf{a}}\right)$ : Hope adds unique variance in predicting entrepreneurial intentions above and beyond that which is predicted by the three theories of planned behaviour constructs. 
Figure 2 above shows that adding hope does not significantly increase the variance explained by the model $\left(\mathrm{R}^{2}=0.377, \Delta \mathrm{R}^{2}=0.001, \mathrm{p}=0.521\right)$. Thus, hope does not add unique variance in predicting entrepreneurial intentions above and beyond that which is predicted by the three theories of planned behaviour variables.

Hypothesis Self-Efficacy $\left(\mathbf{H}_{2 \mathrm{a}}\right)$ : Self-efficacy adds unique variance in predicting entrepreneurial intentions above and beyond that which is predicted by the three theories of planned behaviour constructs.

Self-efficacy does not add unique variance in predicting entrepreneurial intentions above and beyond that which is predicted by the three TPB constructs $\left(\mathrm{R}^{2}=0.377, \Delta \mathrm{R}^{2}=0.001, \mathrm{p}=0.540\right)$.

Hypothesis Resilience $\left(\mathbf{H}_{3 \mathbf{a}}\right.$ ): Resilience adds unique variance in predicting entrepreneurial intentions above and beyond that which is predicted by the three theories of planned behaviour constructs.

Adding resilience significantly increases the variance explained by the model $\left(R^{2}=0.392, \Delta R^{2}=0.016, p=\right.$ 0.009). Thus, resilience adds unique variance in predicting entrepreneurial intentions above and beyond that which is predicted by the three theories of planned behaviour variables.

Hypothesis Optimism $\left(\mathrm{H}_{4 \mathrm{a}}\right)$ : Optimism adds unique variance in predicting entrepreneurial intentions above and beyond that which is predicted by the three theories of planned behaviour constructs.

Addition of optimism to perceived behavioural control, attitudes towards becoming an entrepreneur and close environmental support to the prediction of entrepreneurial intentions resulted in no significant change of the variance explained by the explanatory variables $\left(R^{2}=0.377, \Delta R^{2}=0.001, p=0.564\right)$.

\section{Conclusion}

Existing literature on entrepreneurial intension solely focuses on social norms, perceived behavioural control and attitudes towards becoming an entrepreneur, largely ignoring the influence of positive psychology (Malebana \& Swanepoel, 2015; Herrington \& Kew, 2014; Kolvereid \& Isaksen, 2006; Zhang \& Yang, 2006; Delanoë, 2013; Yousaf et al., 2015). Our findings concur with literature as we found a statistically significant relationship between entrepreneurial intentions and TPB (Kolvereid \& Isaksen, 2006; Zhang \& Yang, 2006; Delanoë, 2013; Kautonen et al., 2013). We found that attitudes towards becoming an entrepreneur $(\mathrm{r}=0.514$; $\mathrm{p}=<0.0001)$; perceived behavioural control $(\mathrm{r}=0.534 ; \mathrm{p}=<0.0001)$; and with close environment support $(\mathrm{r}$ $=0.233 ; \mathrm{p}=<0.0001$ ) had a significant statistical relationship with entrepreneurial intention. Although the three antecedents of TPB were correlated with entrepreneurial intention, the results indicated that the entrepreneurial intention of the participants can be predicted from the attitude towards becoming an entrepreneur and perceived behavioural control. These results are similar to those of Liñán and Chen (2009) in which entrepreneurial intention based on the attitude towards becoming an entrepreneur and perceived behavioural control significantly predicted entrepreneurial intention. The findings corroborate those of Liñán et al. (2013), Liñán et al. (2011), Liñán and Chen (2009), Li (2006) and Krueger et al. (2000) regarding the impact of the attitude towards the behaviour and perceived behavioural control on entrepreneurial intention. The findings also cement previous research regarding the use of the theory of planned behaviour as a valuable model for predicting entrepreneurial intentions (Ajzen, 2005; Souitaris et al., 2007; Basu \& Virick, 2008; Engle et al., 2010; Iakovleva et al., 2011; Mueller, 2011; Angriawan et al., 2012; Otuya et al., 2013). However, our results are contradicting with those of Gird and Bagraim (2008) who reported that an attitude towards becoming an entrepreneur is the best predictor of entrepreneurial intention among university students. Moreover, in a study based on Chinese students by Yang (2013), social norm was the best predictor of entrepreneurial intentions.

However, our findings are consistent with some prior studies (Armitage \& Conner, 2001; Autio et al., 2001; Liñán et al., 2011; Krueger et al., 2000; Schlaegel \& Koenig, 2014) that social norm does not influence entrepreneurial intention. Also in line with Malebana and Swanepoel (2015), our findings revealed that there is no significant effect of entrepreneurial family background on entrepreneurial intention. Close environment support did not significantly affect prospective graduates' entrepreneurial intention $(\beta=-0.005 ; p=0.918)$. Our findings revealed that perceived behavioural control is the best predictor of entrepreneurial intention (Autio et al., 2001; Krueger, 1993; Krueger et al., 2000) and that TPB accounts for more than 35\% of the variance in the explanation of entrepreneurial intention (Krueger et al., 2000). However, Gird and Bagraim (2008) and Schlaegel and Koenig (2014), respectively, found that TPB explained lower percentages (27\% and $28 \%$, respectively) of the variance in the explanation of entrepreneurial intention. A study by Yang (2013) also confirmed the high variance of about $49 \%$ explained by TPB in the explanation of students' entrepreneurial intention. The results of this study did not only provide strong support for TPB in the 
explanation of entrepreneurial intention but also how psychological constructs adds unique variance in predicting entrepreneurial intention above and beyond, which is predicted by the TPB variables among prospective graduates. The researchers were of the view that the adoption of positive psychology adds the prediction power to intention, thus predicting intention becomes more precise.

Fenghua et al. (2013) tested the relationship of psychological capital on entrepreneurial intention and found that hope had no significant relationship to entrepreneurial intention. However, self-efficacy, resilience and optimism had a statistically significant relationship. Our results indicated that entrepreneurial intention was significantly positively related to self-efficacy $(r=0.158 ; p=0.009)$, optimism $(r=0.177 ; p=0.004)$ and resilience $(r=0.255 ; p=<0.0001)$. However, hope had a somewhat statistically significant relationship with entrepreneurial intention $(r=0.118 ; p=0.054)$ as the alpha level was 0.05. Hope had no significant relationship to entrepreneurial intention. Hope, self-efficacy and optimism did not significantly influence the prediction of entrepreneurial intentions. In contrast, in Fenghua et al. (2013) study, self-efficacy and optimism had a positive influence on entrepreneurial intention and entrepreneurial ability. In our study, only resilience significantly influenced the prediction of entrepreneurial intentions and also added unique variance on the prediction of entrepreneurial intentions above and beyond that which is predicted by the three theory of planned behaviour constructs. These findings concur with Fenghua et al. (2013) who found toughness to positively influence entrepreneurial intention and opportunity recognition capability. The researchers concede on the applicability of the theory of planned behaviour and affirm it as a relevant theory in determining intent. To cater for the shortcomings of the theory we adopted, psychological capital is offered as a means to cement and justify entrepreneurial intention. From this finding, entrepreneurial success is likely to be attained by those who enter entrepreneurship and are resilient.

Findings in the study are useful in developing the nation's context as governments and policy makers are looking to entrepreneurship as a measure of reducing unemployment and dealing with global challenges. Focussing on individual traits can further explain why most small organisations fail in the incubations phase; although the notion needs to be further explored, focusing on the positive attributes can remedy this. It is an area of investment which can have an influence on returns. Universities can help in the early identification of these traits and aid in aligning entrepreneurship. These findings help in understanding how prospective graduates can use Psycap in their personal development. This study, among others, has demonstrated the psychological value of the theory of planned behaviour from observable action and to encourage policy makers to target not only the economic attributes but also attitudes and norms of entrepreneurship.

Limitations and areas of further research: As the current study required students to conduct a selfassessment on the constructs under investigation, responses may have been greatly subjective as respondents were influenced by how the students perceived the situation. It would be interesting to conduct a longitudinal study to explore the extent to which intent sums up to actual action. The researchers argue that a longitudinal study would further test the construct under investigation; in as much as entrepreneurial behaviour can be planned; there is a need to explore the extent to which one ends up being an entrepreneur. A qualitative orientation may also give greater meaning to the study findings, especially on the demographics. The study found females to be more resilient than males but did not explore other demographic variables such as race, nationality and age. Testing the same variables in a heterogeneous environment might infer more meaning to constructs.

Contribution: The empirical investigation undertaken has identified resilience as the only psychological capital construct which had a significant influence in predicting entrepreneurial intention among prospective graduates and added unique variance in predicting entrepreneurial intention above and beyond, which is predicted by the theoretical constructs of the theory of planned behaviour among prospective graduates. The findings extend knowledge on the theory of planned behaviour and the driving factors of entrepreneurial intention. Exploring the impact of psychological capital to entrepreneurs' growth intention and performance is not only for academic purposes but stakeholders among them, namely: the state, private sector institutions, prospective entrepreneurs and current entrepreneurs who are interested in entrepreneurial development which starts from entrepreneurial intentions (Yousaf et al., 2015). 
Acknowledgements: The authors are grateful for funding provided by the Research Niche Area within the Faculty of Management and Commerce at the University of Fort Hare.

\section{References}

Ajzen, I. (2011). The theory of planned behaviour: Reactions and reflections. Psychology \& Health, 26(9), 1113- 127,

Ajzen, I. (2005). Attitudes, Personality and Behaviour (2nd edition). Berkshire, England: Open University Press.

Ajzen, I. (1991). The theory of planned behavior. Organizational behavior and human decision processes, $50(2), 179-211$.

Angriawan, A., Conners, S. E., Furdek, J. \& Ruth, D. (2012). An empirical examination of entrepreneurial intent in the equine industry. Proceedings of the Academy of Entrepreneurship, 18(1), 1-8.

Armitage, C. J. \& Conner, M. (2001). Efficacy of the theory of planned behaviour: A meta-analytic review. British Journal of Social Psychology, 40, 471-499.

Autio, E., Keeley, R. H., Klofsten, M., Parker, G. G. C. \& Hay, M. (2001). Entrepreneurial intent among students in Scandinavia and in the USA. Enterprise and Innovation Management Studies, 2(2), 145-160.

Basu, A. \& Virick, M. (2008). Assessing entrepreneurial intentions amongst students: A comparative study. Available online at: http://nciia.org/conf08/assets/pub/basu2.pdf.

Chakraborty, S., Thompson, J. C. \& Yehoue, E. B. (2016). The culture of entrepreneurship. Journal of Economic Theory, 163, 288-310.

Chen, G., Gully, S. M. \& Eden, D. (2001). Validation of a new general self-efficacy scale. Organizational Research Methods, 4, 62-83.

Conner, M. \& Armitage, C. J. (1998). Extending the Theory of Planned Behaviour: A Review and Avenues for Further Research. Journal of Applied Social Psychology, 28(15), 1429-1464.

Dawkins, S., Martin, A. \& Scott, J. (2013). Building on the positives: A psychometric review and critical analysis of the construct of Psychological Capital. Journal of Occupational and Organizational Psychology, 86, $348-370$.

Delanoë, S. (2013). From intention to start-up: the effect of professional support. Journal of Small Business and Enterprise Development, 20(2), 383-398.

Engle, R. L., Dimitriadi, N., Gavidia, J. E., Schlaegel, C., Delanoe, S., Alvarado, I., He, X., Buame, S. \& Wolff, B. (2010). Entrepreneurial intent: A twelve-country evaluation of Ajzen's model of planned behaviour. International Journal of Entrepreneurial Behaviour \&Research, 16(1), 35-57.

Gartner, W. B. \& Shane, S. A. (1995). Measuring entrepreneurship over time. Journal of Business Venturing 10, 283-301.

Gina, G. E. \& Marthine, H. (2013). Psychological capital: Internal and external validity of the Psychological Capital Questionnaire (PCQ-24) on a South African sample. South African Journal of Industrial Psychology, 39(2), 1-13.

Gird, A. \& Bagraim, J. J. (2008). The theory of planned behaviour as a predictor of entrepreneurial intent amongst final-year university students. South African Journal of Psychology, 38(4), 711-724.

Gultekin, A., Sozuer, A., Altan, D. \& Demirtas, T. H. (2013). The Role of Work Hope on Entrepreneurial Selfefficacy and Entrepreneurial Intentions: Evidence from Business Students in Turkey. International Conference on Economic and Social Studies, 10-11 May, 2013, Sarajevo, 1 (1). ISSN 2303-4564

Hamid, M. A. \& Isa, S. M. (2015). The Theory of Planned Behaviour on Sustainable Tourism. Applied Environment Biology Science, 5(65), 84-88,

Henley, A. (2007). Entrepreneurial aspiration and transition into self-employment: Evidence from British longitudinal data. Entrepreneurship and Regional Development, 19(3), 253-280.

Herrington, M. \& Kew, J. (2014). GEM South Africa 2013 Report. Available (online) http://www.gemconsortium.org/docs/3336/gem-south-africa-2013-reportaccessed 11/09/2016.

Iakovleva, T., Kolvereid, L. \& Stephan, U. (2011). Entrepreneurial intentions in developing and developed countries. Education \& Training, 53(5), 353-370.

Kautonen, T., Van Gelderen, M. \& Tornikoski, E. T. (2013). Predicting entrepreneurial behaviour: a test of the theory of planned behaviour. Applied Economics, 45(6), 697- 707.

Keen R., McCoy, M. L. \& Powell, E. (2012). Rooting for the Bad Guy: Psychological Perspectives. Studies in Popular Culture, 34 (2), 129-148. 
Kolvereid, L. \& Isaksen, E. (2006). New business start-up and subsequent entry into self-employment. Journal of Business Venturing, 21, 866-885.

Krueger, N. F., Reilly, M. D. \& Carsrud, A. L. (2000).Competing models of entrepreneurial intentions. Journal of Business Venturing, 15, 411-432.

Krueger, N. F. \& Carsrud, A. L. (1993). Entrepreneurial intentions: Applying the theory of planned behaviour. Entrepreneurship \& Regional Development, 5(4), 315-330.

Küttim, M., Kallaste, M., Venesaar, U. \& Kiis, A. (2014). Entrepreneurship education at university level and students' entrepreneurial intentions Procedia - Social and Behavioral Sciences, 110, 658 - 668

European Commission. (2003). Linking creativity and entrepreneurship. Available: [Online http://ec.europa.eu/education/lifelong-learning policy/doc/creativity/report/oecd.pdf accessed $11 / 09 / 2016$.

Fenghua, X., Haibei, L. \& Le, Q. (2013). Research on the Relation between College Students' Psychological Capital, Entrepreneurial Intention and Entrepreneurial Ability--Based on the empirical analysis of the Chinese college students. Journal of Convergence Information Technology (JCIT), 8, 11, 229-238.

Li, W. (2006). Entrepreneurial intention among international students: testing a model of entrepreneurial intention. [Online] Available at: http://www.sbaer.uca.edu/research/usasbe/2006/pdffiles/toc_cases.pdf. Accessed: 13 March 2006.

Liñán, F. (2004). Intention-based models of entrepreneurship education. Piccola Impresa/Small Business, 3 , 11-35.

Liñán, F. \& Chen, Y. (2009). Development and cross-cultural application of a specific instrument to measure entrepreneurial intentions. Entrepreneurship Theory and Practice, 3, 593-617.

Liñán, F., Nabi, G. \& Krueger, N. (2013). British and Spanish entrepreneurial intentions: a comparative study. Revista de Economia Mundial, 33, 73-103.

Liñán, F., Urbano, D. \& Guerrero, M. (2011).Regional variations in entrepreneurial cognitions: start-up intentions of university students in Spain. Entrepreneurship and Regional Development, 23(3), 187215.

Lortie, J. \& Castogiovanni, G. (2015). The theory of planned behavior in entrepreneurship research: what we know and future directions. International Entrepreneurship and Management Journal, 11, 935-957.

Luthans, F., Avey, J. B., Avolio, B. J., Norman, S. M. \& Combs, G. M. (2006). Psychological capital development: toward a micro-intervention. Journal of Organizational Behaviour, 27, 387-393.

Luthans, F., Avolio, B. J., Avey, J. B. \& Norman, S. M. (2007). Positive psychological capital: Measurement and relationship with performance and satisfaction. Personnel Psychology, 60(3), 541-572.

Luthans, F. \& Youssef, C. M. (2004). Human, social, and now positive psychological capital management: Investing in people for competitive advantage. Organizational Dynamics, 33(2), 143-160.

Malebana, M. J. \& Swanepoel, E. (2015). Graduate entrepreneurial intentions in the rural provinces of South Africa. Southern African Business Review, 19, 189-111.

Marcin, S. \& Katarzyna, A. (2016) Start-up intentions of potential entrepreneurs - the contribution of hope to success. Economic Research-Ekonomska Istraživanja, 29(1), 233-249.

Masten, A. S. \& Reed, M. G. J. (2002). Resilience in development In C. R. Snyder \& S. J. Lopez (Eds.), Handbook of positive psychology (pp. 74-88). Oxford, England: Oxford University Press.

Mónico, L. M., Pais, L., dos Santos, N. R. \& Santos, D. (2014). Psychological capital in Portuguese workers: Contributions to the validity and reliability of the Psycap Questionnaire. Proceedings of the Conferences on Social Sciences and Arts, 1, 319-326.

Mueller, S. (2011). Increasing entrepreneurial intention: effective entrepreneurship course characteristics. International Journal of Entrepreneurship \& Small Business, 13(1), 55-74.

Oldham, G. \& Hackman, J. R. (1980). Work design in the organizational context. Research in Organizational Behavior, 2, 247-278.

Otuya, R., Kibas, P., Gichira, R. \& Martin, W. (2013). Entrepreneurship education: Influencing students' entrepreneurial intentions. International Journal of Innovative Research \&Studies, 2(4), 132-148.

Peng, Z., Lu, G. \& Kang, H. (2013). Entrepreneurial intentions and its influencing factors: A survey of the university students in Xi'an China. Creative Education, 3(8), 95.

Schlaegel, C. \& Koenig, M. (2014). Determinants of entrepreneurial intent: A meta-analytic test and integration of competing models. Entrepreneurship Theory and Practice.

Snyder, C. R., Irving, L. \& Anderson, J. (1991). Hope and health. In C. R. Snyder \& D. R. Forsyth (Eds.), Handbook of social and clinical psychology (pp. 285-305). Elmsford, NY: Pergamon. 


\section{Journal of Economics and Behavioral Studies (ISSN: 2220-6140)}

Vol. 9, No. 1, pp. 166-178, February 2017

Souitaris, V., Zerbinati, S. \& Al-Laham, A. (2007). Do entrepreneurship programmes raise entrepreneurial intention of science and engineering students? The effect of learning, inspiration and resources. Journal of Business Venturing, 22, 566-591.

van Gelderen, M., Brand, M., van Praag, M., Bodewes, W., Poutsma, E. \& van Gils, A. (2008). Explaining entrepreneurial intentions by means of the theory of planned behavior Career Development International, 13(6), 538-559.

Yang, J. (2013). The theory of planned behaviour and prediction of entrepreneurial intent among Chinese undergraduates. Social Behaviour and Personality, 41(3), 367-376.

Yousaf, S. U., Hizam-Hanafiah, M. \& Usman, B. (2015). Psychological Capital: Key to Entrepreneurial performance and Growth intentions. International Research Journal of Social Sciences, 4(9), 39-45.

Walter, S. G. \& Block, J. H. (2016). Outcomes of entrepreneurship education: An institutional perspective. Journal of Business Venturing, 31, 216-233.

Wong, M. \& Choo, S. (2009). Entrepreneurial intention: Triggers and barriers to new venture creation in Singapore. Singapore Management Review, 28(2), 47-64.

Zhang, Y. \& Yang, J. (2006). New venture creation: evidence from an investigation into Chinese entrepreneurship. Journal of Small Business and Enterprise Development, 13(2), 161-173. 